\title{
Volume 5 Issue 3: Editorial, Special Working-Class Poetry Issue
}

\author{
Sarah Attfield, University of Technology Sydney \\ Liz Giuffre, University of Technology Sydney \\ Jen Vernon, Sierra College
}

This issue of the Journal is quite different to previous issues because it is devoted to workingclass poetry. We are very excited to share a selection of poems with you and to hopefully draw your attention to the importance of working-class poetry and the possibilities that can exist in terms of form, style and content.

Over time and place, poetry has helped us communicate ideas and emotions that are difficult to express with straight speech. Rather than evaluate poems as text on a page in relation to others exclusively, the works here ask us to consider context, value, and purpose. What might poetry do for us as an emergent, transnational, diverse, working-class community? How can it help us communicate a working-class ethos, intervene in hegemonic depictions, and imagine new ways of being? Through their focus on poetry, the critics and poets included here illuminate working-class worlds.

Poetry is an excellent medium for expressing working-class life and working-class people from around the world have used poetry to show what it is like to be working class - to convey the feelings and the emotions connected to this experience. It allows for the creative expression of working-class epistemologies and points of view on power. Working-class poets convey them as individuals and members of intergenerational and horizontal collectives.

Working-class poetry tells stories, creates impression, evokes experience and deals with many topics. There are poems about working-class work, whether it be the huge range of manual labour, or white-collar and service work. There are poems about being out of work too and surviving on social security or of relying on the informal economy to make ends meet. Working-class poetry can tell stories of hardship and poverty. The poems can celebrate working-class culture, family and community. They can be nostalgic, but rarely romantic. Poems about working-class life can be tragic or inspiring and uplifting and they can be serious or very funny (sometimes at the same time!). Take note on themes and points of view in working-class poetry. It could be that working-class communities have different ways of dealing with death than middle class peers; sometimes, it might involve jokes. Euphemisms that mask or conceal truths might be less frequently used. Ordinary, poetic subjects like love and beauty and ideals might be articulated differently as working-class poets work hard to make their art say what they mean. Ultimately working-class poems are written about, for and usually by working-class people.

Working-class poetry plays with language and often utilises a working-class vernacular. There might be slang or code-switching between languages and there will be the rhythm of everyday speech. To enhance our communication, we might need to develop an updateable glossary of key-terms as many use vernacular expressions to say what they mean, beautifully. And the 
everyday often dominates working-class poetry. Poems about work, about home, about family reveal much about how class works. These poems don't rely on abstract ideas - they ground them in palpable experience and reveal the concrete, the specific and the small details that speak volumes about what it is like to really be working class.

We can learn much from reading working-class poetry. Xu Lizhi (1990-2014) revealed the conditions for factory workers in a Foxconn factory in China. His poems tell a tragic story of a worker unable to cope with the exploitation. His poems resonate with workers around the world and cast light on the situation for exploited factory workers making products for western markets. Taneum Bambrick writes about working as a garbage collector at reservoirs on the Columbia River in the western US, as one of the few women in the workplace, with poems that reveal the intersections of class and gender. Wanda Coleman's (1946-2013) poems tell stories of life on the poverty line (and you can read an essay about the work of Coleman as well as Jan Beatty and Sandra Cisneros here). The poems of Mykaela Saunders explore class and race and the experiences of being a working class Indigenous Australian. Omar Sakr paints vivid pictures of life in the working-class suburbs of western Sydney and offers poems about being working class, queer and Arab. We encourage you to seek out the work of these poets, and many, many more (we've included a list at the end of this editorial to get you started!).

But you can of course, start with the poets in this issue. The issue begins with an essay by William Fogarty, 'You know all them things': Nostalgia, Idealization, and Speech in WorkingClass Poems by Seamus Heaney, Gwendolyn Brooks, and Lucille Clifton'. Fogarty examines nostalgia in the poems of Heaney, Brooks and Clifton and suggests that the poets' use of language creates unsentimental poems about working-class life. They work across class contradictions between formally educated speech and working-class speech and make a home in and through the poem.

These poets, all dead, but far from gone, continue to provoke and ghost new work. Who can forget Heaney's, the squat pen rests; snug as a gun? We dig with it. This phrase resonates if your hands and your community's hands have held work tools with working-class weight to them. Janet Zandy's research gave us the conceptual tools to talk about this in Hands: Physical Labor, Class, and Cultural Work (2004). And Gwendolyn Brooks documentary approach to poetic practice, and her knowing to listen to lives not heard, is gloriously told in this 6-minute, new media project, 'We Real Cool' (2017). In another 6-minute video, Lucille Clifton, in conversation with Quincy Troupe describes her antecedents coming into poetry which include elements not bound in books. Working-class poetry calls on us to listen. Heaney didn't say a pile of lead he said a gun. Like Wyclef Jean, when I'm writing with a pen it turns into a lethal weapon. Poetry is a place for the expression of righteous rage to provoke change.

Angela Costi's poetic essay 'Unfolding Layers of Labour: A Cross-Generational Account of Kinaesthetic Skills', explores the connections between migrant working-class women across generations through the shared experience of their labour. Costi weaves family history, poems and artistic collaboration throughout her poetic narrative. Hands center in her poems, too, through the work of sewing in factories on industrial machines, working needles, and seeing her mother's hands in her hands as she types the keyboard. Poetry helps us convey the intergenerational embodied experience of class.

A series of poems follows the essays. Lita Kurth writes of being young and getting ready for a night on the town in 'The Goddesses of Democracy Go Out Drinking and Dancing' and also 
writes of her grandmother in 'Josephine Habeck Kurth' - one of the many women who are so important to working-class families and communities.

Jason Yurcic's three poems, 'Albuquerque Summer's Day', '\#3' and '\#5' include stories of work, addiction, pain and joy. There is a sense of pride in the poems at the strength and resilience of working-class people.

In 'upward class (im)mobility' and 'first gen hurt', Sarah Traphagen takes the reader into the world of a working class, first-generation college educated student - a student who has faced class discrimination and the burden of student loans. As we read her work, we should consider how it resonates.

Ian C Smith follows with three prose poems; 'Bright Day', 'Underworld' and 'Rehabilitation', which evoke the experiences of being released from incarceration, and life in a small Australian town, as well as memories of brutality inside a youth detention facility. Smith's focus on incarceration and experiences Inside may be a theme evidenced in some working-class poetry. Yurcic's poems also reference this experience.

'They called her a methhead' is Jodie Childers' challenge to the judgemental attitudes toward working-class people low on the hierarchy whose work and lives and deaths are ignored if they are users. And in 'Mining for Copper' we follow two people who try to make a living by sorting through garbage, looking for anything of value. Here, she brings the older work of mountain mining the community knows to a new form they encounter in the city. The title calls on us to consider the bleak outcome of this rural urban migration and ask, how could working-class lives be better?

Jen Vernon's three poems (which include audio files of the poet reading the work) stem from working-class lives in the US west. 'Charleena Chavon Lyles' is a documentary poem dedicated to a woman by this name who has been elegized by the Black Lives Matter movement. 'Spotted Owl' talks back to rhetoric in a logging town that pits pro-environment and pro-worker as oppositional. 'Economics' applies Karl Marx's species-being concept to an observation of work and draws on the Irish word for labour, 'saothar.' Vernon learned this term from the Irish Labour History Society and their journal by the same name.

The last poem is L. Eva Wagner's 'Reflections from the Parking Lot' which is a 10-minute spoken word poetic memoir about her years spent working as a maintenance mechanic and crew leader on a college campus. Her piece is subtitled, 'Work is Property: A Sexual Harassment Theory.' In the piece, she philosophises the ways in which workspace becomes embodied space connected to one's personhood. As someone who deals with sexual harassment in a male-dominated field and takes pride in her work, how might the body become part of the job and a worker's challenge for jurisdiction over it and their workday and livelihood?

The poems are diverse in style and tone but share commonalities of working-class experience across different time zones and geographical locations. We hope the poems resonate with you and provoke you to write if you are a poet: furiously and vigorously, we need much more. And if you are an appreciator of working-class poetry in its many forms or a critic, we hope that you will seek out more and help us better appreciate it, too. 
The issue also includes seven book reviews selected and edited by Christie Launius. Once again, the reviews demonstrate the growing number of books (both for academic and general audiences) that are focused on working-class life. The reviewers offer their insights into the content of the books and bring a working-class perspective to their reviews. The range of topics is large, with reviews of books on subjects such as Dolly Parton; the stories of coal miners suffering from black lung disease in West Virginia; masculinity and class through the lens of gambling; the issue of downward class mobility and the loss of class privilege; the absence of class analysis in Queer Studies in the US; bankruptcy and its consequences in contemporary Detroit, and a history of a general strike in Seattle in 1919. The reviews are, as ever, thoughtful and offer serious appraisal and evaluation of the books in question.

With 2020 coming to a close, we look forward to a better 2021. We hope to see the Covid-19 pandemic under control, and with lessons learnt on how to look after populations during such an event in the future. Workers around the world will be hoping too that governments will start to act to improve job security and access to health care to prevent the kinds of devastating impact the virus has had on working-class communities. We are sure the momentum of the Black Lives Matter movement will continue, and inroads will be made into dismantling racist structures. And we hope that real action on climate change will be a feature too of 2021 .

Whatever the year brings, we extend warm wishes to our readers, authors, reviewers, guest editors and all who have contributed to this Journal and to the work of the Working-Class Studies Association. We thank you for your commitment to documenting, advocating for, and representing the lives of working-class people - the working-class people who are our families, our friends and our communities. There is still much to be done, but we work together collectively and in solidarity.

\title{
Note
}

Jen Vernon would love to talk with working-class poets about their poems and creative work, please email her at jraevernon@gmail.com.

\section{List of contemporary working-class poets}

(This is just a small list of poets writing in, or translated into English - there are so many more from all around the world!). This list is in first-name alphabetical order. Some of the poets listed here have passed away. The majority of poets in this list are from the U.S.

\author{
Aaron Rudolph \\ Afaa Michael Weaver \\ Allison Adelle Hedge Coke \\ Amber Dawn \\ Amiri Baraka \\ Ana Castillo \\ Cherie Moraga \\ Diane Gilliam Fischer \\ Elizabeth Hodgson \\ Fred Voss
}


Gary Soto

Geoff Goodfellow

Herbert Scott

Jeanetta Calhoun Mish

Jeanne Bryner

Jim Daniels

Joe Weil

John McCullough

Joseph Millar

Joshua Michael Stewart

Leroy Moore

Lorna Dee Cervantes

Lucille Clifton

Mary Carroll-Hackett

Michelle M. Tokarczyk

Mykaela Saunders

Omar Sakr

Paula Meehan

Philip Levine

Pi.O.

Quraysh Ali Lansana

Rita Anne Higgins

Sandee Gertz Umbach

Sean Thomas Dougherty

Shannon Barber

Sue Doro

Susan Eisenberg

Taneum Bambrick

Tina Mozelle Braziel

Tom Lewin

Vievee Francis

Wanda Coleman

Xu Lizhi 